\title{
SOCIAL SIGNIFICANCE OF COLOR
}

Dr. RashmiVerma

Govt. Girls College Neemuch, (M.P.)

India has always been exalted and remembered fondly as country of symbolic colors. To an outsider, its colorful culture, streets, and stories seem like a page out of an ancient folk tale. But color, in essence, has been a large part of the Indian consciousness. From the deep orange marigold flowers that bejewel almost every celebration to the deep hues of red that deck up the bride on her most important day, colour of India has, over time, become synonymous with religion- an expression of faith and beliefs. In a country where a deep understanding of prevalent diversity is perhaps the only common thread that ties its people together, India is a magical experience that ought not to be missed.in a country as diverse and culturally vibrant as India, it is perhaps the common, lifestyles, and tradition. The symbolism of color stand out and control every aspects of life in India, be it religion, politics, festivals, or celebration in India, be it north , south, west, or east, color and culture go hand in hand . Just like many other culture across the world, there are some typical classification of color to be found in India.

COLOR SYMBOLISM IN HINDUISM - For the Hindu, color play a very important role in the religion and culture and have a very deep significance, transcending purely decorative values. Hindu artists use color on deities and their dresses signifying their qualities. Proper use of color used of color creates an environment, which should keep a person cheerful. Some of the main color used in religious ceremonies are red, yellow, and green from leaves, white from wheat flour etc.

$\boldsymbol{R E D}$ indicate both sensuality and purity. In Hindu religion, red is utmost significance and the color most frequently used for auspicious occasions like marriage, birth of a child, festivals, etc. a red mark is put on the forehead during ceremonies and important occasions. As a sing of marriage, women put red powder on hair parting. They also wear a red sari during marriage. Red powder is usually thrown on status of deities and phallic symbols during prayers. It is also the color of Shakti (power). A red color dress is put on deities who are charitable, brave, protective, and who have the capacity to destroy evil. On the death of woman, her body is wrapped in a red cloth for the cremation.

SAFFRON the most sacred color for Hindu saffron. Represents fire and as impurities are burnt by fire, this color symbolizes purity. It also represents religious abstinence. This color connotation has a sacred meaning for the Hindu. It is the color of holy men and ascetics who have renounced the world. Wearing the color symbolizes the quest for light. It is the battle color of Rajput's, the warrior caste.

GREEN is a festive color it represent life and happiness. For that reason, a widow does not wear green. Symbolizing peace and happiness, green stabilizes the mind. Color is cool to eyes and represent nature. 


\section{INTERNATIONAL JOURNAL Of RESEARCH -GRANTHAALAYAH \\ A knowledge Repository}

Art

YELLOW is the color of knowledge and learning. It symbolizes happiness, peace, meditation, competence and mental development. It is the color of spring and activates the mind. Lord Vishnu's dress is yellow symbolizing his representation of knowledge. Lord Krishna and Ganesha also wear yellow dresses. Yellow clothes are warm and yellow food is eaten at spring festivals. Single girls wear yellow to attract a mate and keep evil spirits away.

WHITE - is a mixture of seven different colors hence it symbolizes a little bit of the quality of each. It represent purity, cleanliness, peace and knowledge. The goddess of knowledge, saraswati is always shown as wearing a white dress, sitting on a white lotus. The brhmin - the highest social caste- is associated with white. Hindu religious leaders cover themselves with white ashes to represent their spiritual rebirth. White also the color of mourning. The other prominent deities would also have a touch of white on their dress. A Hindu widow would wear a white dress mourning.

$\boldsymbol{B L} \boldsymbol{U} \boldsymbol{E}$ - The creator has given the maximum of blue to nature the sky, the oceans, the rivers and the lakes. The deity who has the qualities of bravery, manliness, determination, the ability to deal with difficult situation, of stable mind and depth of character is represented as blue colored. Lord Rama and Krishna spent their life protecting humanity and destroying evil, hence they are colored blue. 